INSIGHTS INTO REGIONAL DEVELOPMENT

ISSN 2669-0195 (online) http://jssidoi.org/IRD/

2020 Volume 2 Number 4 (December)

http://doi.org/10.9770/IRD.2020.2.4(7)

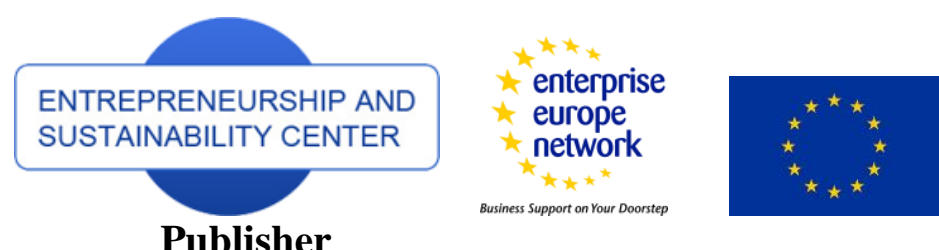

http://jssidoi.org/esc/home

\title{
INFLUENCE OF BREXIT ON EDUCATION TOWARDS EUROPEANISM*
}

\author{
Marcel Lincényi ${ }^{1}$, Martin Laczko ${ }^{2}$ \\ ${ }_{1,2}$ Alexander Dubček university of Trenčin, Študentská 1639/2, 91101 Trenčin, Slovakia \\ E-mails: ${ }^{1}$ marcel.lincenyi@tnuni.sk $;{ }^{2}$ laczko.ml@gmail.sk
}

Received 18 July 2020; accepted 10 October 2020; published 30 December 2020

\begin{abstract}
The present research study explores the extent to which the withdrawal of the UK from the European Union may negatively affect the efforts to lead in particular young people to have a positive attitude towards this integration group, enhance a feeling of belonging to it or a certain sense of common European citizenship. The main aim of the paper was to identify those selected circumstances of Brexit and its campaigns that could evoke strong Eurosceptic sentiments and, on the contrary, look for ways to eliminate these negative tendencies. The authors discuss how a populist, emotionally focused and often misleading campaign has significantly contributed to the vote of Brexit in a referendum, which is a precedent that may under certain circumstances be repeated in other member countries. The paper also discusses the media dimension of the topic. Especially the question of spreading misinformation, hoaxes, conspiracy or propaganda in alternative media that can strengthen Euroscepticism in many EU countries, including the Slovak Republic.
\end{abstract}

Keywords: Brexit; education; European Union; Euroscepticism; media

Reference to this paper should be made as follows: Lincényi, M., Laczko, M. 2020. Influence of Brexit on education towards Europeanism. Insights into Regional Development, 2(4), 814-824. http://doi.org/10.9770/IRD.2020.2.4(7)

JEL Classification: F50, F68, Z11

Additional disciplines: General, Policy, Economics of the Arts and Literature

\section{Introduction}

Brexit, the British referendum on the withdrawal of the United Kingdom of Great Britain and Northern Ireland (further referred to as the United Kingdom) from the European Union, is still an actual topic. The issue of the impact of the UK's withdrawal from the European Union is still a very crucial issue for European or international politics. Brexit, therefore, represents an opportunity to study a unique political phenomenon, which is currently insufficiently professionally researched and still in the process of its development at the time of writing. Especially in the Slovak professional literature, we record a lack of scientific works or publications dealing with

\footnotetext{
* This research was carried out in the framework of the project KEGA 003TnUAD-4/2018: Innovation of methodological letters for teachers of civic education from the point of view of prevention of manifestations of extremism and education for democratic citizenship
} 


\section{INSIGHTS INTO REGIONAL DEVELOPMENT}

ISSN 2669-0195 (online) http://jssidoi.org/jesi/

2020 Volume 2 Number 4 (December)

http://doi.org/10.9770/IRD.2020.2.4(7)

this phenomenon and its impact. "From this point of view, the prevention itself is crucial, which should be applied, among other things, in curriculum at primary schools and secondary schools or grammar schools." (Ćársky, 2019:7) We know that the citizens of Great Britain chose a final divorce with the European Union on 23 June 2016. With this decision, they moved their country to a position in which no other member state of EU has been before. The unprecedented election of British people pushed their country into a new unknown era. It was the start of a long marathon of political negotiations between the two sides, which are still not finished and it is still not clear under what conditions Britain will leave the EU. Dlhá a komplikovaná cesta taktiež viedla aj $\mathrm{k}$ tomuto referendu. "Much of the country, especially England, has always been relatively less inclined and unfavourable about European political integration." (Cremedes, Novak 2017:5) The more or less openly declared goal of most British governments, from the Labor government of Harold Wilson to the government of David Cameron, was to keep further political or economic integration or the merging of sovereignty, to a minimum. Perceptions of European integration were usually negative, and European integration was presented by most media as a process of loss rather than sharing sovereignty (Cremedes, Novak 2017).

During the referendum campaign, many advocates of leaving the EU emphasised the vision of UK independence, which harnesses the potential of its citizens through direct democratic control, as well as national and local selfgovernment and giving maximum freedom and responsibility to its people. There is, therefore, strong opposition to the concepts and ideas of shared sovereignty, multilevel governance at European level, supranational democracy or an ever closer union, in which decisions are taken as close as possible to the citizen following the principle of subsidiarity (Cremedes, Novak 2017).

The UK Independence Party (UKIP), which won almost four million votes (13\%) in the May 2015 elections, has been openly campaigning for the UK's withdrawal from the EU for many years. They were soon joined by several members of the Conservative Party's Eurosceptic wing and even six members of the cabinet. On the other hand, the Labour Party, the Liberal Democratic Party and the Scottish National Party were in a campaign for staying in the EU (Cremedes, Novak 2017).

As the A. Hrubinko (2019, p. 126) wrote, the general public attitude towards European integration was marked by instability, which was caused by insufficient awareness of its citizens, Eurosceptic attitude of leading parties, conservatism of public sentiment and specificity of British identity, anti-European propaganda of the leading press. Contradictory character of European policy of the British governments and the lack of popularity of the unifying tendencies in the region among the local public caused the lack of unity in the question of the future participation of the state in the European Community, the uncertain positions of Great Britain on the eve of key events in the history of European integration related to the formation of the EU laid the basis for further problems in the UK's relations with the EU.

Leaving the European Union is an unprecedented process, and the United Kingdom will be the first country to undergo it. Will it become a model for other EU member states that choose to follow in its footsteps, or will it be a frightening example that such a step can bring more loss than gain?

\section{Methodology and methods}

The research problem that we will address is the degree of harmfulness or usefulness of a Member State's withdrawal from the EU for Great Britain, but also the European Union. The main research goal of the theoretical study was to identify those selected circumstances of Brexit and its campaigns that could provoke strong Eurosceptic sentiments, and instead to look for ways to eliminate these negative tendencies. 
INSIGHTS INTO REGIONAL DEVELOPMENT

ISSN 2669-0195 (online) http://jssidoi.org/jesi/

2020 Volume 2 Number 4 (December)

http://doi.org/10.9770/IRD.2020.2.4(7)

The secondary research objective was to discuss how a populist, emotionally focused and often misleading campaign significantly contributed to the Brexit vote in a referendum. This precedent may be repeated in the other Member States in certain circumstances.

Within the methodology of the work, we determined three research questions:

RQ1: What will be the consequences for the United Kingdom of leaving the European Union?

RQ2: What is the forecast of the most significant impacts of Brexit for the United Kingdom, the European Union and Slovakia?

RQ3: What are the options for increasing the credibility of the European Union and its institutions after Brexit for citizens of EU member states?

Foreign research literature and Internet articles will serve us as a research file.

The methodology we will use in this work consists of analysis of the current state of negotiations on Brexit, review and comparison of possible models of post -Brexit economic cooperation between the EU and Great Britain and forecasts of the most significant impacts of Brexit for Great Britain, European Union and the Slovak Republic.

\subsection{Model and Data}

\section{Forecast of the most significant impacts of Brexit}

We can say that most of the economic, political and social consequences of Brexit will depend on the future of economic cooperation between Great Britain and the EU. The European Union was created mainly as an economic integration structure. The EU's greatest asset is its single market and the customs union, which guarantees the free movement of goods, services, people and capital between the member states of this group. However, with this economic integration is also associated a certain level of political integration. The Member States of the European Union must comply with EU legislation relating to the single market or other EU policies. They must also contribute to the EU's common budget. Political integration is accepted among the Member States with much less enthusiasm than that economical. However, the political and economic integration of the Union is interlinked. No Member State can only enjoy the benefits of its membership in the EU. It must also fulfil the obligations associated with that membership. That is why the future state of trade relations between Great Britain and the EU after Brexit will be crucial. It will be about finding compromises. Britain's goal is to gain as much political freedom as possible from the EU, but at the same time to have the freest possible access to its single market. In other words, the more political freedom the United Kingdom gains from the EU, the more it will cost them in the form of negative economic consequences.

In this chapter, we will try to predict the most significant impacts of Brexit. This prediction will help us to form a picture of whether Britain has a chance to be in a better position after Brexit than when it was a member of the EU. However, we will also talk about what can happen to the European Union after Brexit, especially in the political context. Last but not least, we will also mention the most severe possible impacts of Brexit for the Slovak Republic. 
INSIGHTS INTO REGIONAL DEVELOPMENT

ISSN 2669-0195 (online) http://jssidoi.org/jesi/

2020 Volume 2 Number 4 (December)

http://doi.org/10.9770/IRD.2020.2.4(7)

\section{Brexit Impact Forecast for the United Kingdom}

From an economic point of view, Britain seeks to achieve the highest possible degree of access to the EU single market, but at the same time the least possible compliance with EU acquis, as well as the least possible contributions to the common EU budget. Prime Minister May said the UK would not seek to adopt any model already used by other countries, but instead wanted the British government to enter into an ambitious, comprehensive economic partnership with the EU. (House of Commons, 2018) We can, therefore, rule out the possibility that the United Kingdom would remain a member of the European Economic Area or the Customs Union after Brexit. We may also exclude future trade relations under the terms of the World Trade Organization. Agreements similar to the Canadian CETA or the Ukrainian DCFTA are possible. Canada's Comprehensive Economic and Trade Agreement with the EU eliminates tariffs on trade in industrial products between the EU and Canada. The agreement also includes the substantial elimination of tariffs on agricultural products. CETA also provides a forum for cooperation on regulatory and technical standards for products from both sides, which will allow the exchange of relevant information between EU and Canadian regulators, which will help identify areas where they could cooperate, thus removing some non-tariff barriers to trade. In the case of CETA, it goes well beyond WTO-GATS provisions, allows worker mobility, mutual recognition of professionals, removes certain restrictions in financial services and maritime transport services, and also opens up domestic markets for public procurement. (Emerson. 2017) Another advantage of the EU-Canada CETA agreement is that Canada has access to the EU's single market without having to comply with the EU's legal obligations or contribute to the EU budget. The problem is that the European Union does not want to allow the United Kingdom to, figuratively speaking, pick raisins from a pie. If Britain is to have any access to the single market, it must abide by its rules and pay for it in the EU budget. Being a member of the single market and not being a member of the EU is also a problem that the United Kingdom would have no opportunity or influence to change EU acquis, as it would no longer be represented on EU decision-making bodies. However, the UK wants to retain its ability to influence possible future changes to EU law, which should be transformed into UK law. (Emerson a kol. 2017) Such a provision to change the details of the agreement exists under the DCFTA / Association Agreement with Ukraine, as the lists of EU legislation contained in the annexes to the main text of the agreement may be changed if both parties agree. (Emerson. 2017) DCFTA agreement can ensure a very high degree of access to the EU single market. However, it leads to a high degree of compliance with EU acquis and is therefore outside the category of agreements that the UK would like to reach.

The possibility of a combination of the principles of the CETA and DCFTA agreements, therefore, seems most likely. There could be set up a system under which the United Kingdom would begin its post-Brexit independence in full compliance with EU acquis, but could subsequently deviate from it in a specific sector where it suits it. Such a derogation would, of course, be subject to a mutual agreement. However, as a tax, Britain would lose preferential access to the market for the goods or services in the area, which are governed by directives from which Britain would derogate. (Emerson a kol. 2017) This reaffirms our assumption that the agreement on future British-EU trade relations will be based on the necessary compromises. The more political sovereignty the United Kingdom gains, the more negative economic consequences await it. This means that it will not be possible for the United Kingdom to conclude a preferable agreement with the EU that, with its advantages, exceeds full membership of the European Union. The benefits of acquired political sovereignty could be negligible compared to the negative economic consequences associated with it.

The economic impact of Brexit will also be dependent on the agreed financial settlement between the EU and the United Kingdom. If the goal of Brexit is to free the country from the costly financing of the EU budget, we can say that it can succeed in the long term, but only if the UK no longer remains a member of the single market or the customs union. However, Britain will have to pay a relatively expensive divorce bill of around 35 to 39 billion pounds. (Keep, 2018a) Britain will also continue to pay for participation in programs in which it wishes to maintain membership as well as contributions to the pensions of European employees, which will be a relatively 


\section{INSIGHTS INTO REGIONAL DEVELOPMENT}

ISSN 2669-0195 (online) http://jssidoi.org/jesi/

2020 Volume 2 Number 4 (December)

http://doi.org/10.9770/IRD.2020.2.4(7)

low annual payment, but it will last for decadesHowever, what works in favour of Britain is that it should no longer pay for access to the single market and membership of the customs union. The paid-up capital from the EIB and the ECB will also be returned to the UK. The shrinking of the British economy and the fall of the pound against the euro could be seen mainly as a negative impact, but the positive is that, as a result, Britain will again contribute a little less to the EU (Curtis. 2017).

Another area in which Britain is to gain more sovereignty after Brexit is control over migration from EU countries. Citizens' rights, which will be part of the Brexit Agreement, will apply to those UK citizens and EU citizens, including their family members, who exercised their rights to free movement within the EU / UK before the date set for Britain's withdrawal from the EU. We can, therefore, say that people living and working in the UK will have the right to remain in the UK without the need for visas or other residence permits.

The British government has succeeded in gaining the right to require EU citizens living in Britain to apply for status and freedoms under the Brexit agreement. By this, the government wants to gain more overview and control over EU immigrants. Given that everything in the agreement is reciprocal, it may happen that some or all EU Member States will similarly demand the same from UK citizens. As regards the rights of foreign nationals to social welfare, EU and British negotiators have agreed that the rules on social security coordination will continue to apply to EU citizens who are covered by the UK social security system or British nationals who are or have been included in the social security system of a particular EU Member State until the date of withdrawal from the EU. (Curtis. 2017) This seems like enough compromise to suit both the UK and the EU. Britain will be able to require visas and residence permits from new EU migrants who have not yet lived there. EU citizens already living and working in Britain will have the right to stay there after Brexit. They will not be required to have any visas or residence permits. They will also continue to be covered by the social security system.

The land border between Northern Ireland and the Republic of Ireland also remains an important issue. It should change from a symbolic internal to a solid external border of the EU after Brexit. Both the EU and the United Kingdom have pledged to prevent a fixed border on the island of Ireland. However, without Britain being a member of the single market and the customs union, this will be very difficult to achieve. The proposals to resolve this situation submitted by the United Kingdom did not satisfy the EU. The possibility of full compliance with the rules of the single market and the customs union has been moved to the preliminary EU withdrawal agreement. (House of Commons 2018) While this would certainly remove the need for a land border, it is again at odds with Britain's plans to leave the EU's single market and customs union. If Britain wanted to keep only Northern Ireland in the customs union, a border would have to be created in the Irish Sea, which would cut the region off from the rest of the country. This would have negative effects on trade not only in the United Kingdom but also in Ireland. This possibility was therefore rejected by the British Government. In any case, for now, it looks like Britain, with its current position, will have to establish a solid border with Ireland after Brexit. This would have several adverse effects, in particular, related to cross-border trade and people's mobility. Such a border would also be contrary to the Treaty of Good Friday, and a breach of that Treaty could jeopardise the fragile peace between Great Britain and Ireland.

Not all authors are determined whether Brexit will be positive or negative for the UK. „But what is better for Great Britain, stay in or go out? There is no universal answer to this question. It depends which way we look at it or what we believe is important." (Melus, 2016, p. 462). 


\section{INSIGHTS INTO REGIONAL DEVELOPMENT}

ISSN 2669-0195 (online) http://jssidoi.org/jesi/

2020 Volume 2 Number 4 (December)

http://doi.org/10.9770/IRD.2020.2.4(7)

\section{Brexit impact forecast for the EU and Slovakia}

The departure of Great Britain forms the EU should not mean significant economic damage to the European Union as a whole. The biggest downside is that the EU will lose one of its most significant net contributors to its budget. The United Kingdom will continue to contribute to this budget, but a much lesser extent than before Brexit. A significant advantage for the EU may be that large banks, financial service providers or British companies can start relocating to the EU, which can create a lot of new jobs in the EU and strengthen its economy. Brexit's challenges for the EU are mainly political. The very vote for Brexit in the UK has sparked a wave of nationalism and Euroscepticism across Europe. Questions have arisen about the future viability of the European Union. (Ford, Goodwin, 2017) Many European (far-right) political parties and movements have included in their electoral programs a request to give the citizens of their country a similar opportunity to decide in a referendum on membership in the European Union as a people in the UK did. Some of these parties have failed, such as the French National Front of Marine le Pen or the Dutch Independence Party of Geert Wilders. However, many parties may have achieved small or more significant victories thanks to such a policy. An example is that several European Eurosceptic, nationalist and populist political parties were elected to their national parliaments. The Alternative for Deutschland party, which is often described as neo-Nazi, has entered the German parliament. The populist Freedom and Direct Democracy party of Tomio Okamura entered the Czech parliament, and the referendum on the EU was one of the mainstays of this party's election campaign. In Slovakia, the far-right Kotleba - the People's Party of Our Slovakia, entered the parliament after the last elections This party is currently the loudest critic of the European Union of all Slovak parliamentary parties and is also pushing for a referendum on EU membership. If the support of the Eurosceptic parties continues to grow, the EU may lose more members in the future. On the other hand, the Union will by Brexit get rid of its most critical member and biggest opponent of European political integration. For the EU, this means an opportunity for even deeper political integration. In the future, therefore, it may happen that the European Union will no longer be just an integration grouping, but will become a kind of superstate based on the principle of the federal establishment. So it could become something like the United States of Europe.

Slovakia is one of those countries in the European Union that is likely to experience the harmful effects of Brexit. Britain is the 5th largest export market for Slovakia, our exports to the United Kingdom represent more than 5\% of GDP, only four European countries have a higher ratio. (KPMG, 2017) In the case of labour mobility, Slovakia is also in slight risk. Still, the Brexit negotiations have already reached an agreement on preserving the rights of EU citizens living in the United Kingdom and the British living in the EU Member States. So there are likely to be specific groups of people who will have the right to live and work in the UK. Still, the new administrative procedures for applying for this status may make it more difficult or impossible for them to exercise these rights.

The share of exports to Britain in terms of total exports or as a percentage of GDP ranks Slovakia among the countries that will be most affected by Britain's exit from the EU single market. Exports to the United Kingdom accounts for the largest share of the total exports in Ireland (4.17\%), Slovakia (3.27\%), Spain (2.87\%) and Germany (2.54\%). If we take into account the share of exports to Britain in relation to GDP, Slovakia is one of the most endangered countries. Within the EU member states, Luxembourg has the largest share of exports in GDP to the UK with $10.1 \%$. It is followed by Malta (9.1\%), the Netherlands (7.6\%), Belgium (7.3\%) and Slovakia (5.2\%) closes the top five (KPMG, 2017).

Cars account for almost half of exports to the UK. The United Kingdom is the second-largest export market for our car manufacturers and every seventh car made in Slovakia goes to Britain. Following the UK's exit from the single market, exports to the British Isles can be more complicated for all car manufacturers in continental Europe, to what extent, that will be determined by a final agreement between the UK and the European Union (Melioris, 2016). 


\section{INSIGHTS INTO REGIONAL DEVELOPMENT}

ISSN 2669-0195 (online) http://jssidoi.org/jesi/

2020 Volume 2 Number 4 (December)

http://doi.org/10.9770/IRD.2020.2.4(7)

Another economic impact of Brexit for the Slovak economy is a slowdown in GDP growth; most economists and analysts expect a slowdown in Slovak GDP growth in the range from one-tenth to two-tenths of a percentage point due to Brexit. A more severe problem is the expected slowdown in economic growth in more of the euro area countries, which could again have a negative effect on Slovak exports. The downturn in the British economy will have a direct impact on our exporters. However, our economy will feel a more pronounced effect secondarily through the slowdown of our main trading partners. The impact of growing uncertainty and weakening investor and consumer confidence will also be substantial, especially in Britain, but also in other EU countries. The strengthening of the euro against the pound and the currencies of neighbouring countries will worsen the price competitiveness of Slovak exporters. (Melioris a kol., 2016) According to estimates by the National Bank of Slovakia, the Slovak economy due to Brexit could experience a slowdown in the economic growth of $0.34 \%$ by 2020. In 2017, the NBS estimated the economic growth of the Slovak Republic at the level of 3.3\% and the creation of approximately 80,000 new jobs by 2018. However, the departure of the United Kingdom from the EU could, according to NBS analysts, affect these forecasts and create 5,300 fewer jobs in Slovakia by 2020 (Vravec, 2017).

One of the indirect effects may be the return of a large number of Slovaks from the British labour market home to Slovakia. (Vravec, 2017) Another indirect impact for Slovakia may be the fact that Brexit means the departure of a member of the Union who pushed for modernisation and progressive economic reforms. Britain's withdrawal from the EU may reduce the pro-reform efforts and innovation potential that the country has represented within the Union.

On Wednesday 2 May 2018, the European Commission presented a draft of the new post-brexit budget of the European Union for the years 2021-2027. The Commission presented a budget of almost $€ 1.14$ trillion ( $€ 1.28$ trillion when inflation is taken into account), representing $1.11 \%$ of the total economic output (after Brexit) of the 27 EU countries. This represents a slight increase over the current budget for 2014-2020, which amounts to $€ 1.09$ trillion (1.03\% of the EU's economic output). (TASR, 2018) For EU member states, including Slovakia, this will mean higher contributions to the EU budget. The system by which the EU wants to penalize the Member States violating the EU law is also interesting. Under this mechanism, compliance with EU law will be linked with access to EU money. This means that in the event of non-compliance with them, Union funds for a particular state will be frozen (TASR, 2018). This could be seen as a new political tool through which the EU wants to force some rebel states to be more in line with their policy and thus to deeper political integration.

To sum it up, the extent of Brexit's adverse economic impact on Slovakia will depend on the shape of the future trade agreement between the United Kingdom and the European Union. The United Kingdom is the fifth-largest export market for us. If it does not secure access to the single market in the negotiations, the Slovak economy may be negatively affected by the introduction of tariff and non-tariff barriers in international trade. Brexit can also slow our economic growth and job creation. It may increase the Slovaks' tendency toward Euroscepticism and reduce their efforts to reform the EU. Another impact of Brexit may be the return of a large number of Slovaks from the British labour market to Slovakia. That could help the Slovak malnourished labour market. However, it is possible that if Slovaks begin to return en masse from Britain, there will not be enough jobs at home for them. If Britain succeeded in negotiating a free trade agreement, at least in the area of goods, the negative economic impact on Slovakia would be considerably smaller. Due to the loss of Great Britain's contributions to the EU budget, Slovakia will contribute more to the EU and receive less from it. As for the effects of Brexit on Slovaks living in Great Britain, their further stay in this country should not be endangered by Brexit. It also applies to some of their family members and children. The only problem may be the process of applying for the new resident status provided by the Brexit Agreement, some people may fail in this process, may not know about it or may not be able to prove their stay or work sufficiently. The reason for the mass withdrawal of Slovaks from Britain may be the weakening of the British economy. Working and living in the UK may no longer be so beneficial for Slovaks, so many of them may decide to return home. 
INSIGHTS INTO REGIONAL DEVELOPMENT

ISSN 2669-0195 (online) http://jssidoi.org/jesi/

2020 Volume 2 Number 4 (December)

http://doi.org/10.9770/IRD.2020.2.4(7)

\section{Problem Solution}

The referendum on Britain's withdrawal from the European Union is a unique and unprecedented phenomenon. The study shows several conclusions:

The final agreement will be a compromise between gaining greater political sovereignty of Britain and the negative economic consequences that would result from it. The final agreement could, therefore, take the form of a comprehensive, in-depth economic partnership, in which Britain could choose in which segment of the common market it wants to have preferential access. However, it would have to comply with EU legislation applicable to the selected market segment. The EU is likely to ask Britain for financial contributions to its budget, for any preferential access to its single market.

We also analysed the outcome of the Brexit negotiations to date, which were published in a joint report by the United Kingdom and the EU in December 2017. It helped us to find out what the financial settlement between the UK and the EU might look. Assuming that the UK wants to free itself from the costly financing of the EU budget, it can be said that it can succeed in the long term, of course, it will also depend on the extent to which it has access to the EU's single market. Britain will also have to pay a Divorce bill of around $£ 35$ to $£ 39$ billion. It should continue to contribute for participation in programs in which it wishes to maintain membership. Britain will also continue to contribute to the pensions of European employees, which will be a relatively low annual contribution, but this contribution will last for decades. However, what works in favour of Britain is that it should no longer pay for access to the single market and membership of the customs union. However, this depends on the degree of access to this market that could be negotiated in the framework of a new comprehensive trade agreement. However, the UK's access to the EU market is far from as complex as that of EU membership. Therefore, if there will be some contributions to the EU single market in the future, they are likely to be much lower than at present. The paid-up capital from the EIB and the ECB will also be returned to the UK. The shrinking of the British economy and the fall of the pound against the euro could be seen mainly as a negative impact, but the positive thing is that as a result, Britain will again pay the EU a little less. Exactly how much Britain will pay for Brexit will not be known until all payments related to the withdrawal have been made. However, the estimated cost of this break-up looks more favourable than if Britain were to continue to pay high net contributions to the EU budget each year.

Another area in which Britain is to gain more sovereignty after Brexit is control over migration from EU countries. Citizens' rights, which will be part of the Brexit Agreement, will apply to those UK citizens and EU citizens, including their family members, who exercised their rights to free movement within the EU / UK before the date set for Britain's withdrawal from the EU. It can, therefore, be said that people living and working in the UK will have the right to stay there, without the need for visas or other residence permits. However, the United Kingdom will require EU citizens to register their residence in the country after Brexit. Given that everything in the agreement is reciprocal, it is possible that some or all EU Member States will similarly demand the same from UK citizens. As regards the rights of foreign nationals to social welfare, EU and British negotiators have agreed that the rules on social security coordination will continue to apply to EU citizens who are covered by the UK social security system or British nationals, who are or have been included in the social security system of a particular EU Member State until the date of withdrawal from the EU. It is a fair two-way compromise, it will give the UK more control over immigration from the EU, but at the same time, people who already live in the UK will have the right to continue to live and work in it.

On the issue of the Irish border, we have found that the United Kingdom has not yet provided a sufficiently comprehensive and workable solution to exit the single market and the customs union while maintaining an open and invisible land border between Northern Ireland and the Republic of Ireland. Currently, a solid border is most likely to be created on the island of Ireland, which will have substantial implications for imports and exports 


\section{INSIGHTS INTO REGIONAL DEVELOPMENT}

ISSN 2669-0195 (online) http://jssidoi.org/jesi/

2020 Volume 2 Number 4 (December)

http://doi.org/10.9770/IRD.2020.2.4(7)

between Ireland and the United Kingdom. It can also directly jeopardise the Good Friday Agreement, which guarantees peace and cooperation between the Irish and the British.

\section{Conclusion}

Given the aim of our work, we can say that the United Kingdom will not be in a better position with Brexit than under its membership in the European Union. The positive effects of the financial balance between the EU and the United Kingdom, stronger control over immigration and greater political sovereignty will not offset the negative economic impact of leaving or restricting access to the EU single market or abolishing membership of the European Customs Union. Thus, with our final hypothesis, we assume that Brexit will do more harm than good to the UK.

As wrote Kamil Kotlinki (2018, str. 157), the effects of the United Kingdom leaving the EU will be more unfavorable for the UK than for the EU. The amount of losses depends on the type of Brexit. A soft Brexit means a relatively slow negotiation designed to retain as close as possible a relationship with the rest of the EU. Access to the EU's single market will reduce losses due to having as few tariffs as possible. A hard Brexit would mean getting out of the EU quickly, having no institutional or political relationship with the union, and regaining full control of UK borders. Therefore, a negotiated free trade deal with the EU would seem to reduce losses for everyone.

According to Jean Arthuis (2018, str. 37), Brexit is a chance for Europe. It casts a cruel light on the institutional fragility of the European Union, whose functioning is hardly defensible to public opinion.

In the article, we also set a partial goal, which is to predict the most severe possible impacts of the Brexit for the European Union, including the effects for the Slovak Republic. Perhaps the most substantial economic impact for the European Union will be the fact that it will lose one of the most significant net contributors to its budget and the second strongest economy of all member states. The relocation of large British companies, banks and financial service providers to EU countries can be a significant positive. The draft of the European Commission's new postBrexit budget, which was presented in May 2018, already counts with losses. It should be a combination of cuts and higher contributions from the Member States. Also noteworthy is the proposed mechanism that would allow the EU to financially penalise the Member States for their inadmissible proceedings. This is just one more indication that the EU will work even harder for greater political integration. The EU will undoubtedly want to take advantage of the fact that the most critical member of its political integration will leave it. It is, therefore, possible that in the future, the EU will have an even more significant impact on the policies of its Member StatesEurosceptic, populist or far-right parties in Europe will fight against this. Brexit has given inspiration to such parties if they continue to gain momentum, it is possible that the EU will lose more members in the future.

The extent of the negative economic impact of Brexit for Slovakia will again depend on the shape of the future trade agreement between the United Kingdom and the European Union. The United Kingdom is the fifth-largest export market for us. If Britain does not secure access to the common market in the negotiations, the Slovak economy may be negatively affected by the introduction of tariff and non-tariff barriers in international trade. For example, the important export of our cars can be significantly affected. Brexit can also slow our economic growth and job creation. It may increase the Slovaks' tendency toward Euroscepticism and reduce their efforts to reform the EU. Another impact of Brexit may be the return of a large number of Slovaks from the British labour market to Slovakia. Due to the loss of Great Britain's contributions to the EU budget, Slovakia will contribute more to the EU and receive less from it. As for the effects of Brexit on Slovaks living in Great Britain, their further stay in this country should not be endangered by Brexit. It also applies to some of their family members and children. The only problem may be the process of applying for the new resident status provided by the Brexit Agreement, some people may fail in this process, may not know about it or may not be able to prove their stay or work sufficiently. 


\section{INSIGHTS INTO REGIONAL DEVELOPMENT}

ISSN 2669-0195 (online) http://jssidoi.org/jesi/

2020 Volume 2 Number 4 (December)

http://doi.org/10.9770/IRD.2020.2.4(7)

Brexit in the United Kingdom, after the European economic crisis, the migration crisis is another important reason why the negative moods of citizens in the European Union are increasing. The authors, therefore, believe that the Council of the European Union and the European Commission can contribute to increasing citizens' credibility with the European Union by addressing issues that affect EU citizens as a matter of priority. "Representatives of the Slovak Republic in European institutions play a vital role, including members of the European Parliament, who should explain the positives of EU membership to the citizens of the Slovak Republic" (Bočáková, Lincényi, 2014, p. 50).

The authors also agree with several authors that a positive identity with membership in the European Union could be enhanced by more intensive citizenship education. "The European dimension of education and training is still relevant not only in the old member states of the European Union but also in the new or future member states" (Hubálek, Lincényi, Staněk 2018, p. 56).

Last but not least, an effective marketing and media campaign could help to improve public opinion on the European Union's action as well as on citizens' trust in the European institutions. Such a campaign should be carried out throughout the European Union under the coordination of the European Commission. (Lincényi, 2018, p. 433)

\section{References}

CREMEDES, M. T., NOVAK, P. 2017. Brexit and the European Union: General Institutional and Legal Consideration. [E-Reader Version]. Retrieved from https://www.europarl.europa.eu/thinktank/en/document.html?reference=IPOL_STU(2017)571404

ČÁRSKY, J. 2019. The importance of media education in terms of prevention against extremism in the subject of Civic education in Slovak republic. In: Sborník z VIII. Mezinárodní vědecké konference studentú doktorských studijných programú v oblasti společenských věd. Praha: Nakladatelství Epocha, 2019. ISBN: 978-80-7557-240-0. p. 7.-14.

EMERSON, M., 2017. An Assessment of the Economic Impact of Brexit on the EU27. European Parliament. Brussels.

FORD, G., GOODWIN, M. 2017. Britain After Brexit. In Journal of Democracy. [E-Reader Version]. Retrieved from: https://www.journalofdemocracy.org/articles/britain-after-brexit-a-nation-divided/

VRAVEC, J. 2017. Analýza vybraných ekonomických aspektov odchodu Vel'kej Británie z Európskej únie (Analysis of selected economic aspects of the UK's exit from the European Union). FINANČNÉ TRHY. ISSN 1336-5711, 1/2017 1-7

CURTIS, J. 2017. Brexit: 'sufficient progress' to move to phase $2 . \quad$ Retrieved from: https://researchbriefings.files.parliament.uk/documents/CBP-8183/CBP-8183.pdf

HOUSE OF COMMONS. 2018. The land border between Northern Ireland and Ireland. Retrieved from: https://publications.parliament.uk/pa/cm201719/cmselect/cmniaf/329/329.pdf

KEEP, M. 2018. The UK's contribution to the EU Budget. Retrieved from: https://researchbriefings.parliament.uk/../Summary/CBP-7886

KPMG. 2017. Odhad vplyvu Brexitu na Slovensko (Estimation of the impact of Brexit on Slovakia). Retrieved from: https://home.kpmg.com/sk/sk/home/media/press-releases/2017/03/slovensko-patri-medzi-krajiny-eu-najviac-ohrozene-brexitom.html

MELIORIS, L. 2016. What will Brexit bring? Estimation of the impact of Brexit on the Slovak economy. Retrieved from: http://www.finance.gov.sk/Default.aspx?CatID=11174

TASR. 2018. Eurokomisia predstavila návrh nového rozpočtu EÚ po odchode Británie (The European Commission presented a draft of the new EU budget after Britain's departure). Retrieved from: http://www.teraz.sk/najnovsie/ek-predstavila-navrh-noveho-rozpoctu/322899$\underline{\text { clanok.html }}$ 


\section{INSIGHTS INTO REGIONAL DEVELOPMENT}

ISSN 2669-0195 (online) http://jssidoi.org/jesi/ 2020 Volume 2 Number 4 (December) http://doi.org/10.9770/IRD.2020.2.4(7)

LINCÉNYI, M. 2018. Prieskum názorov Slovákov na budúcnost' Európskej únie (A survey of the opinion of the citizens of Slovak on the future of the European Union). Proceedings of the 19th International Scientific Conference "International Relations 2018: Current Issues in World Economy and Politics": Bratislava : Ekonomická univerzita, 424-435.

HUBÁLEK, T., LINCÉNYI, M., STANĚK, A. 2018. A comparative analysis of pupils' and teachers' public opinion on European citizenship and European identity in the Czech Republic and the Slovak Republic, 2018. Economic Annals-XXI. ISSN 1728-6220. 171, (56), 50-56.

BOČÁKOVÁ, O., LINCÉNYI, M. (2014). Perception of Slovakia's membership in the European Union from the perspective of Slovaks, 2014. In: Proceedings of the 2nd international conference on European integration 2014. - Ostrava: VŠB, 43-50.

HRUBINKO, A. 2019. The way to Brexit: A socio-political dimension of Great Britain's participation in the processes of European integration. In UKRAINSKYI ISTORYCHNYI ZHURNAL, 6, 126-141,

KOTLINSKI, K. 2018. The economic consequences of leaving European Union by Great Britain. EKONOMIA I PRAWO-ECONOMICS AND LAW, 17(2), 157-167.

ARTHUIS, J., FARRELL, H. 2018. What future for a democratic Europe following brexit? TOCQUEVILLE REVIEW, 39(1), 37-48

MELUS, M. 206. REFERENDUM ABOUT "BREXIT" AND FURTHER DEVELOPMENT IN GREAT BRITAIN. Proceedings of 14th international scientific conference: Economic policy in the European union member countries. 462-470

\section{Acknowledgements}

This research was carried out in the framework of the project KEGA 003TnUAD-4/2018: Innovation of methodological letters for teachers of civic education from the point of view of prevention of manifestations of extremism and education for democratic citizenship.

Short biographical note about the contributors at the end of the article (name, surname, academic title and scientific degree, duties, research interests):

Marcel LINCÉNYI, PhD. in Media studies, obtained at Constantine the Philosopher University in Nitra, currently at Department of Political Science as associate professor, Trenčín University of Alexander Dubček in Trenčín (TnUAD), Slovakia.

ORCID ID: https://orcid.org/0000-0002-9076-026X

Martin LACZKO, Mgr. is currently external PhD. student at the Department of Political Science, Alexander Dubček University of Trenčín in Trenčín, Slovakia

ORCID ID: https://orcid.org/0000-0002-9620-2541

Make your research more visible, join the Twitter account of INSIGHTS INTO REGIONAL DEVELOPMENT:

@IntoInsights

Copyright (C) 2020 by author(s) and VsI Entrepreneurship and Sustainability Center

This work is licensed under the Creative Commons Attribution International License (CC BY).

http://creativecommons.org/licenses/by/4.0/

CC) (7) Open Access 